\title{
Public participation in urban noise prevention
}

\author{
Z. Baros ${ }^{1}$ \& L. Dávid ${ }^{2}$ \\ ${ }^{1}$ Institute of Agroinformatics and Rural Development, \\ Károly Róbert College, Hungary \\ ${ }^{2}$ Department of Tourism and Regional Development, \\ Károly Róbert College, Hungary
}

\begin{abstract}
The so-called 'soft factors' are playing an increasing role in urban planning. Alternative strategies based on these can include bottom-up initiatives in which citizens intend to find solutions to noise-related problems in their settlement through their participation and in accordance with their requirements. This paper intends to give a brief introduction to the role of individuals regarding their participation in such programmes, based on the literature available and the results of a questionnaire survey carried out in the Town of Debrecen (East Hungary). The results of the survey indicated that the overall picture of the residents' opinions on noise pollution is rather contradictory: they basically seem to perceive the impacts and the relevance of this issue, however, in general, the respondents did not recognise their own roles in resolving the problem itself neither as 'polluters' nor as 'endurers'.

Keywords: noise nuisance, sustainable urban development, liveability, mental infrastructure, public participation, noise prevention programmes.

\section{Introduction}

Humankind seeks better quality and more secure housing. On the basis of the available literature, it is quite difficult to define better quality housing. One aspect, however, is clear, a healthy physical or built environment is a necessary precondition for the viability of settlements [1]. The condition of the environment (i.e., air, soil, water, noise, etc.) is, in addition to the quality of life, one of the main factors influencing urban tourism [2], a sector considered to be a major priority in the economic development of the town of Debrecen, which is the focus of this study.
\end{abstract}


Noise nuisance is one of the most severe problems impacting urban residents. According to estimations by the OECD, more than half of the citizens in Europe live in noisy environments and about one third of them are exposed to high noise levels at night causing sleep disturbances [3]. Noise management is gaining increasing prominence as a factor in the protection of the urban environment today. As a consequence, it is now an integral part of all environmental impact assessments [4]. Environmental noise is recognised as an indicator of the quality of the environment [5] and integrated urban development strategies place great emphasis on the management of noise-induced environmental problems. Successfully combating noise pollution thus represents a major step towards the establishment of an urban environment that provides an adequate quality of life [6].

\section{Sustainable urban development, quality of life and noise nuisance}

According to Juhary-Koroknay [7], residents' level of comfort in a given district depends on the following factors: protection of the individuals including protection against noise impacts; adequate living conditions; and the establishment of symbiosis. The first factor, namely, the desire for a peaceful and quiet residential environment or an improved level of acoustic comfort motivates the majority of intra-urban movements in residential areas. This had been a decisive factor already in the late $1980 \mathrm{~s}$, accounting for $15 \%$ of movements from the city centre of Cologne to its environs [8].

The specific 'noise characteristics' of the residential area and workplace [9] are created jointly by various sources of noise. Most public opinions on the environment of residential areas and factors influencing property prices (i.e. the quality of the living environment, the age and construction of the property) are directly or indirectly linked to the noise characteristics of the area [10]. The overall view of the acoustic comfort or, in a broader sense, on the characteristics of the noise conditions can contribute to the district's image, its attractiveness and the property prices and influences perceptions of liveability [6]. This last is one of the four main development objectives of the World Bank's new urban strategy, developed at the turn of the millennia [11], whose strategic central objective is support of sustainable urban development. Most of the criteria focus on social sustainability with a lesser concern for sustainability of environmental conditions. Comparing these to the factors applied to benchmark social sustainability (i.e., Sustainability Value Map) developed by Butters [12], it can be concluded that, in addition to security, the only other common factor is 'quality of life accessible for all' (Fig. 1).

\section{Methods}

The following sections include a review of the roles of three potential actors (i.e. the municipality, civil organisations and the individuals) in sharing 


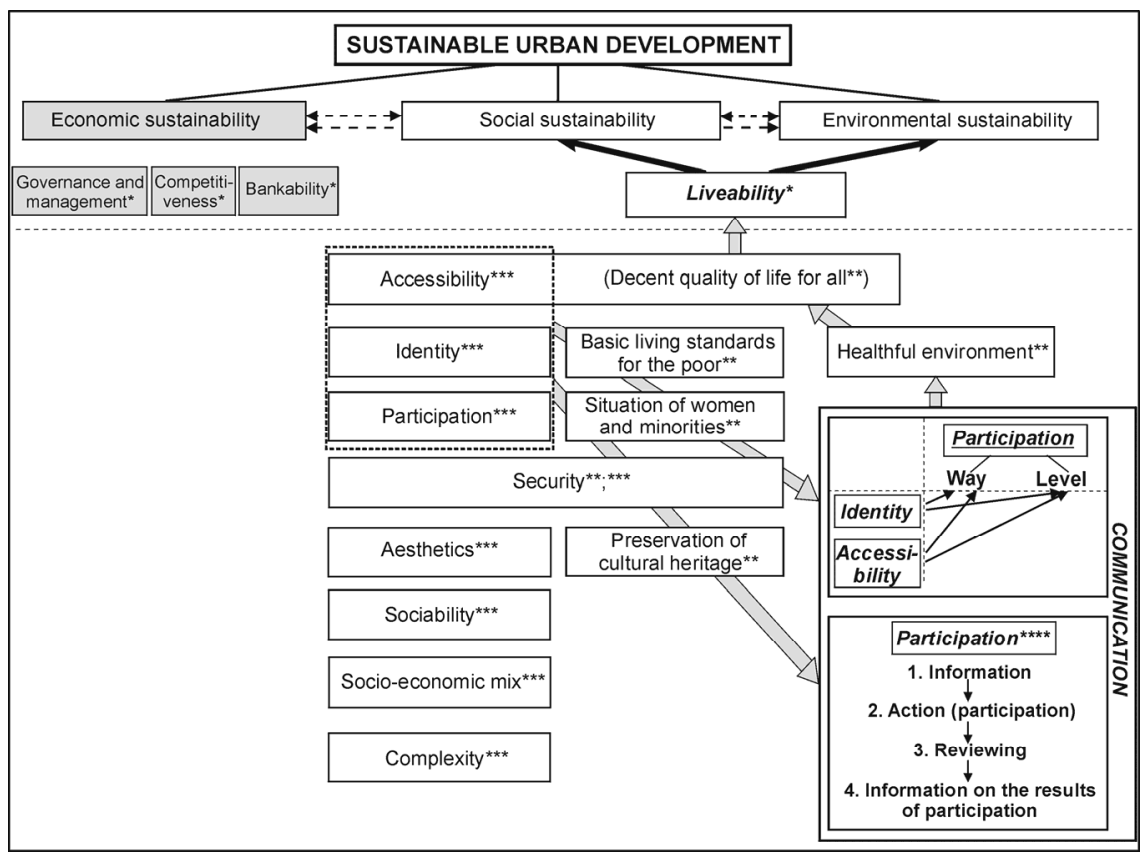

Figure 1: Social dimensions of sustainable urban development and its relationship to public participation in solving environmental problems [6]. *Dimensions of sustainable urban development according to the World Bank [11]; **Main development measures to be taken in order to achieve 'liveability', according to the World Bank [11]; ***Social dimensions of sustainable development according to Butters [12]; ****Steps of public participation in the management of noise nuisance related problems (modified after Bonacker [13]).

responsibilities for noise pollution abatement and a discussion of the results of a questionnaire survey of the opinions of residents on noise nuisance, which was conducted in the Town of Debrecen (East Hungary) [10].

The survey included questions on the type and level of disturbance caused by noise as experienced at the respondent's home, workplace and in the street and where in the town the highest noise-levels were experienced. Questions were also asked about the most important sources of noise emissions, and on the level of noise pollution contributed by transportation. The time and duration of noise nuisance and potential ways of eliminating the existing problems were included in the set of questions (Table 1).

A representative sample of 909 respondents was selected from typical builtup districts throughout the town. In total, 169 streets were classified, partly by studying transportation networks and partly from our own experience, into three categories by road traffic intensity (with high, intermediate and low traffic) and their proximity to other sources of noise (railway, industrial facilities, etc.). 
Table 1: $\quad$ Main topics of the questionnaire applied [10].

\begin{tabular}{|l|c|c|c|}
\hline & Dwelling & Workplace & Street \\
\hline The level of noise-related disturbance & $\checkmark$ & $\checkmark$ & $\checkmark$ \\
\hline $\begin{array}{l}\text { The source of noise judged to be the most } \\
\text { relevant and most disturbing }\end{array}$ & $\checkmark$ & $\checkmark$ & $\checkmark$ \\
\hline Disturbances caused by transportation & $\checkmark$ & $\checkmark$ & $\checkmark$ \\
\hline $\begin{array}{l}\text { The time and duration of the highest and lowest } \\
\text { disturbance/the period the situation exists }\end{array}$ & $\checkmark$ & $\checkmark$ & \\
\hline $\begin{array}{l}\text { The impacts of noise-related disturbances on the } \\
\text { life of the respondents }\end{array}$ & $\checkmark$ & $\checkmark$ & $\checkmark$ \\
\hline The noisiest locations of the town & & $\checkmark$ \\
\hline Noise nuisance and abatement at the workplaces & & $\checkmark$ \\
\hline The health impacts of noise & & $\checkmark$ \\
\hline $\begin{array}{l}\text { Possibilities for noise mitigation and the } \\
\text { measures taken }\end{array}$ &
\end{tabular}

According to local people, the Town of Debrecen can be referred to as a noisy Hungarian town. Disturbances caused by road traffic are evident throughout, especially along the main transportation routes. The duration of noise nuisance experienced in residential areas is considerable to which must be added noise at the workplaces and in the street. The effects of perceived noise nuisance on the quality of life is represented by occasional or regular (not necessarily frequent) sleep disturbances, primarily among the residents living near roads with severe traffic [10].

\section{Potential actors to manage urban noise as an environmental conflict}

Environmental noise as a problem is local in terms of its management but is largely non-local in its origins. However, it can be tackled and successfully prevented when thoughtful problem management is implemented at the local and international levels [14]. Moreover, putting forward the principles of subsidiarity and joint responsibility is demanded increasingly by both the EU and the Hungarian legislation [15].

Questionnaire surveys with a high number of respondents can be useful for urban planning and development in indicating areas where the implementation of noise prevention measures are most demanded by the inhabitants. These data can provide important guidelines in developing urban environmental programmes, which in the long run, can address relevant urban environmental problems at the local level [10].

\subsection{Municipalities}

In addition to the road traffic noise, the so-called 'disco-issue' or the clamour arising from places of entertainment at night combined with the noise of patrons' 


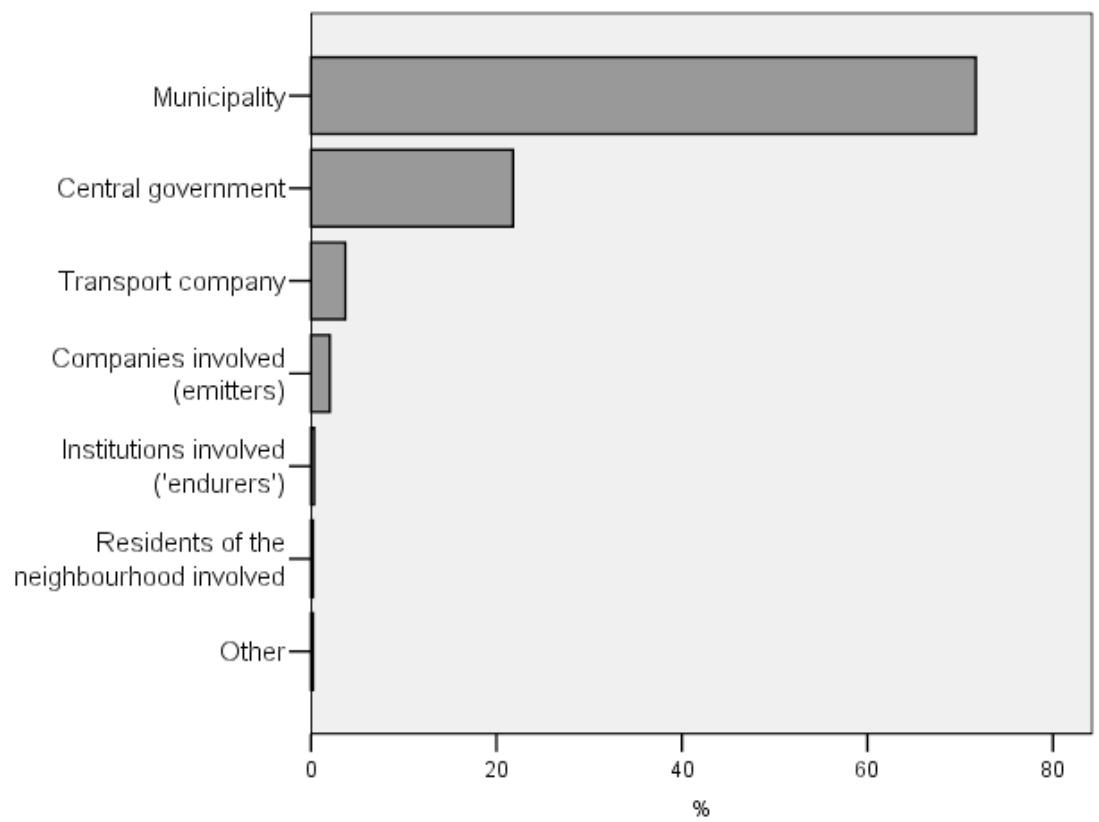

Figure 2: Public opinions on the role of initiator in the management of noiserelated problems in Debrecen (\%) [6].

vehicles is an issue in nearly all municipalities [16]. The results of the survey indicated that more than $70 \%$ of the respondents expected such noise-related disturbances to be solved by the municipality [6], fig. 2 .

However, at the present time, municipalities do not have the power to combat these disturbances through legislation, as this power is reserved by central government. In effect, stricter noise abatement regulations than that currently legislated by central government can only be introduced by the municipalities if the actual framework had been previously defined by law or governmental decree. At present, this is not the case [17].

\subsection{Civil organisations}

In Hungary, since the regime change, civil organisations have become relevant social and economic influences active in environmental protection. This is further supported by their role in networking, knowledge and capital. The application of the principle of subsidiarity also underlines the necessity for civil organisations' involvement in the management of the local environmental problems. Despite the above and for a number of other reasons, this social intertwining and division of labour is in its very early stages. It is also evident that, in many cases, civil organisations are regarded as a tool not as partners by institutes functioning in the field of environmental development [18]. 
The minimal role of civil organisations is indicated by the fact that they were marked as potential initiators (in the category 'Others') by only approximately $2 \%$ of the respondents [6] (Fig. 2).

\subsection{The individuals}

One of the subjective features of towns is the awareness of the local people [19]. The way residents manage their potentials and problems, how they establish their environment and atmosphere and how they develop their lives is termed as the town's mental infrastructure by Kiss [20]. According to this author, instead of the 'hard', technical factors, the emphasis should be focused on these "soft" factors in planning, strategy and programme development.

Such alternative strategies based on 'soft' factors can be the basis of bottomup initiatives in which residents create their own living environment by participation, cooperation with each other and with the aid of professionals. Such joint initiatives can establish community 'life' [1].

Worldwide, an increasing number of initiatives focus on growing public participation in environmental impact assessments partly because it has been recognised that dialogue ensures a more detailed knowledge on environmental impacts and can contribute to tackling related conflicts and practical problems [21].

The individual's capacity for participation (i.e., the extent and way of participation) will be, on the one hand, influenced by his/her knowledge on noise nuisance influenced by access to relevant information and his/her level of interest. This latter is influenced by the (individual and community) identity and, as part of it, the level of environmental consciousness (Fig. 1). Prior to structured public involvement, it is important to survey opinions on the relevance of noise nuisance as an environmental problem affecting them. With these data in hand, effective action plans can then be developed. On the basis of the results of the questionnaire survey, the following can be claimed [6]:

a. How important is noise nuisance apparent around the individuals? Seventy-four per cent of the respondents are disturbed to some extent in their dwellings by noise. It was concluded that the most important source of noise nuisance $(26.1 \%)$ was traffic noise. In addition, dust and air pollution from traffic were also indicated as problems (Fig. 3).

Finally, to the question whether noise can harm human health, only $7.7 \%$ of the respondents answered 'no' and a further $6.9 \%$ marked 'don't know'. Apparently, they are aware of the consequences and experience them during their every-day lives.

b. How the respondents see their roles in relation to the problem? On the one hand, it is interesting that for transportation within the town, 34.5\% uses their own car, and $51.9 \%$ use public transportation and $15.2 \%$ cycle or walk. This high use of public transport is not due to environmental awareness but rather to low income. Less than half of the respondents $(43.6 \%)$ expressed the intention to minimise noise emissions during their everyday activities. This is a criterion for even 
fewer (just over 20\%) when purchasing technical appliances. The overall picture is even less encouraging when the individual is seen as the 'endurer' of noise levels, as approximately two thirds (61.2\%) make little effort to reduce their exposure to the harmful effects of noise.

\section{Public participation}

Participation can be ensured in many ways (workshops, round table meetings, Internet forums, etc.); however, formal involvement of the public should be preceded by appropriate information to select affected target groups [13] and a survey of their awareness and sensitivity to noise nuisance (Fig. 1). By being familiar with public opinion, the features and reasons underlying noise-related problems can be systematically explored and followed up by developing strategies to address the most significant and relevant areas of noise abatement. Knowing the attitude of respondents enables those areas where public involvement could be most effective to be defined [6].

The overall picture drawn from the results of the questionnaire survey carried out among the citizens of Debrecen is rather contradictory. Citizens basically

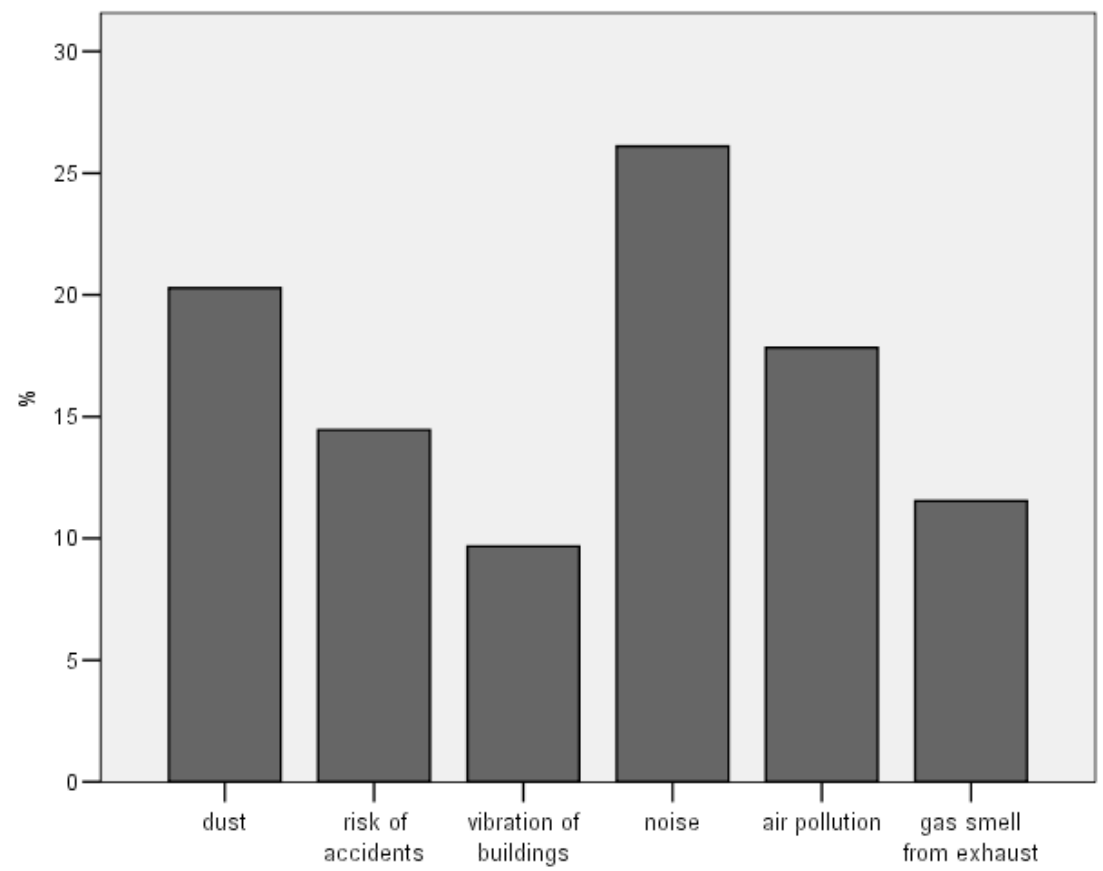

Figure 3: Opinions on the negative impacts of road traffic as according to the public (\%) [6]. 
perceive the relevance of the issue and are aware of its impacts but they do not recognise their own role in solving it - neither as 'emitters' nor as 'endurers' [6].

A more detailed statistical analysis of the survey data is beyond the scope of this article, and the above discussion is simply a summary of the main conclusions the aim of which is to emphasise the importance of public participation.

What could be the objectives of such an urban community noise prevention programme? Providing and extending the information on the health impacts of noise, noise-related complaints, noise levels and regulation, learning about a settlement's mental noise maps, strengthening the cooperation of professionals and laymen or even influencing/altering the individual's transportation, consumption and behavioural habits. An effective way of achieving an improved noise environment could be the presentation of the advantages resulting from noise abatement, the introduction of improved noise insulation techniques or noise standards for buildings, and, finally, a demonstration of noise nuisance as an externality of transportation and, through this, better accounting of the total social costs of transportation.

As a consequence of the above, it is important to implement the integration of individual and social responsibility as part of communicative-collaborative urban ecological planning [20]; i.e. as an environmental conflict, noise pollution should be the focus of the highest possible level of public involvement. In this way, the quality of environment, both in the narrow (residential area) and the broader sense (settlement) could be improved, which would contribute to achieving one of the major objectives of urban planning, namely "a decent quality of life for all" (Fig 1). By such efforts towards a healthier urban environment, the social dimensions of sustainable development can be significantly strengthened [22, 23] as well as advancing the realisation of a settlement's ecological sustainability (Fig 1).

\section{References}

[1] Meier, R.L., Ecological Planning, Management, and Design, 2003 - Online manuscript:

www.ced.berkeley.edu/pubs/faculty/meier_richard/ecoplanmgmtdes/

[2] Michalkó, G., The Theory and Practice of Urban Tourism, MTA Földrajztudományi Kutató Intézet: Budapest, 168 p., 1999. (in Hungarian)

[3] Nardo, M., Noise Pollution: an Overview of Management Strategies. International Journal of Environmental Technology and Management, 4 (4), pp. 300-322, 2004.

[4] Buna, B., Experiences of Noise Impact Studies in Hungary. Assessment of Environmental Impacts, ed. Flórián Gy., a TEM 13, Közlekedéstudományi Intézet: Budapest, pp. 21-29, 1994. (in Hungarian)

[5] Hatta, L., The Impacts of Noise on Humans, OMIKK Környezetvédelmi füzetek, 27 p, 2000. (in Hungarian)

[6] Baros, Z., Public Participation in Urban Noise Prevention. Proceedings of the $2^{\text {nd }}$ Conference on Urban Environment (Debrecen, 27-28 $8^{\text {th }}$ Nov. 2009), 
Debreceni Egyetem Tájvédelmi és Környezetföldrajzi Tanszék: Debrecen, pp. 94-99, 2009. (in Hungarian)

[7] Juhary-Koroknay, A., The Relationship between the Quality of Homes and the Acoustic Comfort. CD-proceedings of the Noise Prevention Seminar The Actual Issues of Noise Prevention (Debrecen, 8-10 $0^{\text {th }}$ Nov. 2006), OPAKFI, 2006. (in Hungarian)

[8] Penn-Bressel, G., Verkehrslärm und Wohnstandortverhalten. Informationsdienst un Mitteilungsblatt des deutschen Volksheimstättenwerks, 41, pp. 145-148, 1988.

[9] Fodor, I., Environmental Protection and Regionalism in Hungary. Dialóg Campus Kiadó: Budapest-Pécs, pp. 224-235, 2001. (in Hungarian)

[10] Baros, Z. \& Gajdátsy, P., Public Opinions on Road Transport Induced Noise Nuisance in the Town of Debrecen. Proceedings of the $1^{\text {st }}$ Conference on Urban Environment (Debrecen, 8-10 $0^{\text {th }}$ Nov. 2007), Kossuth Egyetemi Kiadó, Debreceni Egyetem: Debrecen, pp. 134-139, 2008. (in Hungarian)

[11] World Bank, Cities in Transition. World Bank Urban and Local Governments Strategy, World Bank: Washington, 2000

[12] Butters, C., A Holistic method of Evaluating Sustainability, 2004. Online. www.gaiaoslo.no/artikler.html

[13] Bonacker, M., Participation Process according to Directive 2002/49/EC. CD-proceedings of Forum Acusticum (Budapest, $29^{\text {th }}$ Aug- $2^{\text {nd }}$ Sept 2005). Budapest, 2005. (in Hungarian)

[14] Bite, P. \& Póta Gy., EU Guidelines and their Enforcement in the Transportation Induced Noise Prevention in Hungary. Közlekedéstudományi Szemle, 51(7), pp. 241-256, 2001. (in Hungarian)

[15] Hungarian Academy of Sciences, Section of Engineering Sciences, Complex Committee of Acoustics, Environmental Noise Prevention in Hungary and its Development Strategy with Special Focus on the EU Requirements, Budapest, 45 p, 2003. (in Hungarian)

[16] Dávid, L. et al. (ed), The Environmental Programme of the North Great Plain Region in Hungary, Észak-alföldi Regionális Fejlesztési Ügynökség: Debrecen, 150 p, 2003. (in Hungarian)

[17] Vizeli, S., The Role of Municipalities in Noise Prevention. CD-proceedings of the Noise Prevention Seminar - The Actual Issues of Noise Prevention (Debrecen, 8-10 ${ }^{\text {th }}$ Nov. 2006), OPAKFI, 2006. (in Hungarian)

[18] Bucher, E., Civil Organisations for the Development of the Urban Environment - with examples from the County of Baranya. CDproceedings of the $3^{\text {rd }}$ Hungarian Conference of Geography (Budapest, 6$7^{\text {th }}$ Sept. 2006), 2006. (in Hungarian)

[19] Bujdosó, Z., The Urbanization in Hungary during the last decade- is it an economic interest or a question of prestige to be graded a town in our country nowadays? Cross-Border Co-operations - Schengen Challenges, ed. Süli-Zakar, I., Kossuth Egyetemi Kiadó: Debrecen, pp.232-237, 2004. 
[20] Kiss, A., Conscious Urban Development. Landscape, Environment and Society - Honorary Studies for Prof. Ilona Kevei-Bárány, Szeged, pp. 363372, 2006. (in Hungarian)

[21] Soneryd, L. \& Weldon, S., Noise and newts: Public Engagement in the UK and Sweden. Environmental Impact Assessment Review, 23, pp. 17-37, 2003.

[22] Swedish Council for Sustainable Development (SCSD). Make Your Municipality Sustainable (An Introduction to Local Tools and Working Methods for Sustainable Development). Online. www.hallbarhetsradet.se/ upload/publikationer/Make your_muni_webb.pdf

[23] Puczkó, L. \& Rátz, T., The Impacts of Tourism - An Introduction. Häme Polytechnic, Finland, 406 p, 2002. 